\title{
Institutional resistance to transparency: the quest for Public Sector Information in Mexico
}

\author{
Guillén Torres, University of Amsterdam
}

Forthcoming in Journal Of Resistance Studies Volume 5, Number 2.

\begin{abstract}
Despite the popularization of progressive Freedom of Information and Open Data policies, both transparency practitioners and academia have warned about an increase in attempts to control and reduce the information that flows from the state to citizens. Within the literature dedicated to investigate this phenomenon, the notion of resistance to transparency has been used often to characterize instances of problematic governmental information control. However, within this body of research, the concept of resistance has been stripped of its contentious elements and treated as a synonym of reluctance, unwillingness or foot-dragging, rather than a category with an inherent political dimension. As a result, what is institutional resistance to transparency and what are its political consequences remains vague. Drawing from the theoretical toolbox of the fields of Resistance Studies and Science and Technology Studies, this paper explores the politics of institutional resistance to transparency through a case study of Mexican information activists. By focusing on activists' experiences, I suggest that institutional resistance originates in how transparency mechanisms allow some citizens to make the state more legible, controllable, and accountable. Furthermore, I argue that institutional resistance is carried out mostly through everyday, subtle, seemingly non-political strategies implemented by the state's institutions, which reduce citizens' ability to produce and/or process data regarding governmental action.
\end{abstract}

\section{Introduction}

Although governmental transparency has become a core component of liberal democracies (Bennett 1997; Birchall 2011; Relly 2012), most countries around the world continue to struggle with varying degrees of institutional opacity (World Justice Project 2015). In fact, despite the popularization of progressive Freedom of Information and Open Data policies (Zuiderwijk \& Janssen 2014; Ackerman \& Sandoval-Ballesteros 2006), both transparency practitioners and academia have warned about an increase in attempts to control and reduce the information that flows from the state to citizens (Rumbul 2016; Almanzar, et al. 2018). Arguably, the widespread concern with the surge in opacity originates in how novel forms of civic engagement, enabled by Public Sector Information (PSI) or Open Data (OD), have become crucial for the performance of modern democracy. Despite the uncertain connection between transparency and accountability (Fox 2007; Hood 2010; Gaventa \& McGee 2013), ample evidence suggests that access to governmental information empowers citizens and strengthens democracies (Fox 2015; Fenster 2015). Thus, academics, investigative journalists, organized activists and individuals have found in the Right of Access to Information (RTI) a tool to fuel advocacy, anti-corruption work (Peisakhin \& Pinto 2010) and academic research (Savage \& Hyde 2014).

The increasing tension between progressive RTI legal frameworks and the historical institutional opacity of modern liberal democracies has inspired a substantial amount of academic literature. Researchers from the fields of Political Science, Law and Information Policy have dedicated considerable attention to the shortcomings of Freedom of Information (FOI) laws as well as the formal and informal institutional practices that hinder citizens' use of the RTI (Roberts 2006). Within this literature, the notion of resistance to transparency has been used often to characterize situations in which public officials refuse to enact transparency laws (Berliner \& Elrich 2015), avoid complying with laws once they are in force (Darch \& Underwood 2005; Gill \& Hughes 2005), or 
boycott their everyday performance with the goal of preserving secrecy within institutions (Pasquier \& Villeneuve 2007). However, despite resistance showing up continuously in transparency literature, the concept has been stripped of its contentious elements -except for few exceptions (i.e. Gentile 2010)- and treated as a synonym of reluctance, unwillingness or footdragging, rather than as a category with an inherent political dimension. As a result, what is institutional resistance to transparency and what are its political consequences remains vague.

The notion of resistance to transparency is nevertheless worthy of careful analysis because it implies a reversal in how the concept of resistance is usually employed in academic literature. In contrast to other widely studied resistance practices, the resistance identified by transparency scholars is performed by the state's institutions rather than subordinate groups or individuals. Thus, the aim of this paper is to shed light over such conceptual inversion, to foreground the political dimension of resistance to transparency. To do so, I draw from the theoretical toolbox of the fields of Resistance Studies and Science and Technology Studies, to explore whether the resistance that transparency scholars talk about is similar to what is the object of study for resistance scholars. As a case study, I focus on how Mexican information activists experience, make sense of and counteract institutional resistance to transparency while gathering and processing data produced by the state.

The main argument of the paper is that, at least in the Mexican case, resistance to transparency consists of sociotechnical practices that produce institutional opacity as a reaction to civic attempts to exercise the RTI. I suggest that institutional resistance originates in how transparency mechanisms can be leveraged by skilled individuals to make the state more legible (Scott 2018), controllable, and accountable, in a context of increasingly more restrictive information policies (Braman 2006). Furthermore, I argue that institutional resistance to transparency is chiefly carried out through everyday, subtle and seemingly non-political actions implemented by institutional actors, rather than official policies that would be controversial in the age of open government. Since the effect of these institutional practices is a reduction in citizens' ability to produce and/or process data regarding governmental action, and thus, a decrease in their power and agency, I suggest that they share features with what Resistance Studies has called Everyday Forms of Resistance (Scott 1989; Vinthagen \& Johansson 2013).

Although research has located instances of resistance to transparency in many countries around the world, ${ }^{1}$ in this paper I focus specifically on the experiences of Mexican information activists: citizens who have found in FOI a key input for their political projects. The case of Mexico is worth approaching given the discrepancy between the high quality of its transparency and open government legal frameworks, ${ }^{2}$ and their less than satisfactory performance, ${ }^{3}$ Furthermore, Mexico's status as a consolidating democracy with an advanced but underperforming legal framework makes the insights of this case study relevant for strong institutional contexts, in which resistance to transparency is made possible mainly by the over-technification of bureaucratic procedures, such as North America and Western Europe, as well as weak institutional contexts,

\footnotetext{
${ }^{1}$ For example, see (Roberts 2006; Bertot et al 2010) for the U.S., (Gingras 2012) for Canada, (Brobbey et. al. 2013) for Uganda, (Calland \& Bentley 2013) for India, (Eom 2014) for Korea, and (Darch \& Underwood 2005) for South Africa, among others.

${ }^{2}$ Despite its multiple reforms, the Mexican Law has been consistently ranked amongst the best since its inception in the early 2000s. Currently, it holds the second place in the Right To Information Index built by Access Info Europe and the Centre for Law and Democracy (Access Info 2017).

3 Mexico is consistently ranked amongst the most opaque and corrupt countries around the world, according to international organization Transparency International (Transparency International 2017).
} 
where institutional resistance seems to be engendered by corruption and/or lack of capacities and funding, such as in most of Africa and Latin America.

The paper is divided into four sections. The first presents the research methodology and the theoretical framework that guides it. The second contrasts the concepts of resistance as they are used in Resistance Studies and literature on transparency. In section three I dive into the Mexican case study, showing how institutional resistance is a reaction to PSI potential to increase citizens' agency Finally, section four summarizes the findings and indicates areas of further research.

\section{Methodology}

The empirical material used for this paper originates from face to face interviews with 15 Mexican information activists who make extensive use of the Freedom of Information process as input for their political activities. One in-depth, semi-structured interview was carried out with each informant during March and November, 2018. The resulting data was anonymized and processed through a security protocol detailed in Kazansky \& Milan (forthcoming). The professional backgrounds of the interviewees are varied. Some of them work on the defense of the rights to water and sanitation, others develop advocacy projects related to sexual and reproductive rights. Their social backgrounds are also diverse, including highly educated professionals as well as activists without higher education qualifications. Although less varied, the political spectrum of the interviewees is not homogeneous: at least two organizations represented in the material could be described as located in the center rather than left side of the activist spectrum. Rather than being a haphazard collection of interviewees, this diversity of activities, backgrounds and political orientations is intended to show that the institutional resistance experienced by activists is not the consequence of their specific politics or topical interests, but a common phenomenon in Mexico.

The analysis of the empirical material, as well as my engagement with activists, was inspired by Annemarie Mol's anthropological work. Mol's approach, representative of the branch of ontological-turn-influenced STS (Mol 1999; Law 2002), often rejects a priori definitions of the objects of study, privileging instead attention over how multiple local enactments may result from the different practices in which the object is manipulated (Mol 1999). Thus, although in this paper I start with an academic definition of resistance, I privilege activists' descriptions of their experiences interacting with institutions. What emerges from such analysis of activists' accounts does not exhaust the state and resistance as abstract phenomena, but rather refers to the specific assemblage (Carroll 2012) activists experience during their everyday life. By analyzing the experiences of a variety of activists, I attempt to show how aggregated local instances of institutional resistance paint a picture that may be relevant at more macroscopic levels.

In writing this paper I also take advantage of my own experience as an information activist working for a Mexican Civil Society Organization for three years. Such insider view allows me to remain faithful to activists' embodied accounts (Haraway 1988), and provide a closer reading of their experiences, rather than the distant one that is more common to the FOI literature. In that sense, this is an exercise of sociology written from the standpoint of those who are the protagonists of the research (Smith 2005).

\section{Resistance to transparency}

Resistance's conceptual fuzziness and popularity as an analytical tool has sparked various efforts, particularly from scholars within the emerging field of Resistance Studies, to clarify its meaning (Baaz et al. 2018; Johansson \& Vinthagen 2015; Hollander \& Einwohner 2004). Within this literature, the considerable diversity of resistance practices and the importance of their varying contexts has 
been of particular interest. However, despite a conscious theoretical attunement to conceptual and contextual diversity, studies of resistance tend to focus on the practices of subordinated actors, on the basis of an assumption that they interact with power within a preconfigured structure in which the roles of the powerful and the powerless are clearly defined and stable (Miller 1997). Therefore, even if what counts as resistance can vary considerably, scholars seem to agree in that practices of resistance are those through which subordinate actors achieve social change (Baaz et al. 2018).

Resistance scholars' preference for structural power asymmetries and progressive social change thus results in a reduced curiosity for actions that, although also effecting social change, do not bring about a progressive state of affairs. As a consequence, whereas practices of talking back to power (hooks 1989) performed by subordinated groups are easily regarded as resistance, the practices of powerful actors to oppose empowered subordinates are not understood as such, but as "reaction" or "counter-resistance". While such distinction allows for a productive differentiation between the way dominators and resistors act, it also runs the risk of stabilizing both positions as if they permeated every social interaction in which either actor is embedded. Resistance scholars are aware of such problem, (cfr Hollander \& Einwohner 2004), but to this date few examples exist that focus on occasions in which resistance is exerted by actors who appear to be structurally more powerful from the perspective of the researcher.

Whereas the distinction between dominators and subordinates is easy to employ in contexts where there is little doubt about what actors exert power over others, the interaction between citizens and governmental institutions of modern liberal democratic states is more difficult to characterize in stable terms. Public officials can, and indeed often do, abuse their access to the state apparatus to achieve dominance or private gains, but they are also subjected to increasingly more citizen scrutiny, accountability and control. Thus, in the interaction between empowered citizens and public officials, and particularly in the current context of Open Government reforms, it may not always be immediately clear what actor is more powerful than the other. The institutional resistance identified by transparency scholars is a case in point. Unfortunately, reflections around resistance within the transparency literature have not approached this complexity.

The way in which transparency scholars have engaged with the idea of resistance varies widely across the body of research I consulted for this paper, ${ }^{4}$ but it is possible to group the discussion

\footnotetext{
${ }^{4}$ The selection of the literature was carried out in the following way: both Google Scholar and Web of Science were queried for scholarly articles and books containing both the terms "resistance" (and variances) and "transparency". The initial results were filtered to produce a set in which "resistance" and "transparency" both referred in some way to the Right to Information. A further selection was performed by locating those texts in which the references to resistance were more substantial, resulting in 29 texts. The literature reviewed here is that which makes more than superficial references to the topic. I have intentionally left out the literature produced within Organizational Studies, which has mainly focused on organizational resistance to change when FOI laws are enacted. Although this is one of the most productive approaches in terms of the amount of studies produced, I have decided not to discuss them given that they look exclusively at what happens when FOI laws are implemented for the first time. In contrast, my focus in this paper is on the resistance to consolidated FOI frameworks. I also have chosen not to comment on widely cited research into institutional reactions to transparency initiatives which do not explicitly mention resistance. For example, What happens when transparency meets blame avoidance?, by Christopher Hood (2007) is not discussed, despite its exploration of ways in which institutions manage to remain opaque. The reason is that my interest here is to engage with research that
} 
under three main types of arguments. In the first, resistance is understood as a reaction to how FOI alters the relationship between citizens and institutions (Fox 2015; Worthy 2010; Darch \& Underwood 2010; 2005; Terrill 2000). Researchers reflect around the effects that access to information legislation has over the power dynamics of liberal democracies, and FOI related laws and mechanisms are described as reconfiguring and even subverting citizen-state relationships. Therefore, resistance is considered a rational response from public officials to the possibility of FOI radically changing the power configuration of decision-making processes.

The second type of argument presents resistance as a predictable reaction originating from obdurate cultural traits within public administration (Meijer 2013, Brobbey et al. 2013, Bauhr \& Nasiritousi 2012, Pasquier \& Villeneuve 2007, Gill \& Hughes 2005). Here, researchers tend to focus on how transparency collides with a deeply rooted culture of secrecy and opacity, and argue that access to PSI may produce adverse reactions because public officials have traditionally thought of files and archives as their property, or because secrecy allows for a feeling of independence within decision-making processes.

A third take on resistance to transparency understands it as a problematic, but seldom illegal, practice within public administration through which officials may use regulatory frameworks in an opportunistic fashion to avoid accountability. Alasdair Roberts work is the best example of this type of research (2006), although he chooses to go with the concept of non-compliance rather than resistance, which suggests that, within his framework, what officials resist are the laws forcing them to disclose, and not the citizens who set them in motion to access PSI. Resistance is indeed mentioned in his extensive study Blacked Out (2006), albeit only a handful of times, and as a synonym of non-compliance. As a consequence, the political dimension of public officials' resistance is dislocated and de-politicized, since their struggle is not primarily with citizens but with legal norms.

Either of these three takes on institutional resistance to transparency seem to approach the concept less as it is used within the social sciences -always in relation to power- and more as it is understood in physics: an opposition exerted by an object or flow to the flow of an electrical current (Diantith \& Martin 2005). In consequence, there is hardly any consideration within the broader transparency literature about how institutional resistance affects the FOI-backed political engagement of citizens. Although Michener and Ritter, two influential transparency researchers, have argued that "it is difficult to distinguish between political resistance and resistance as an indirect effect of limited capacities" (Michener \& Ritter 2017, p.11), I argue that this difficulty can be surmounted by approaching resistance to transparency through the conceptual tools of Resistance Studies.

In what follows I will depart from a generic definition of resistance as an act of opposition that undermines power in order to achieve social change (Baaz et al 2018; Lilja et al. 2017), but I will introduce two nuances. First, while much discussion in the field of Resistance Studies has been centered on whether it is intent or recognition what defines resistance (Shaw 2001), I will argue that the experience of the effect can also count as definitive; resistance is whatever is felt as such by any actor, regardless of the temporary place they hold within the power position when researchers open it up for analysis. Thus, individual's perception of the power of others can also give the researcher an indicator of the presence of resistance (Miller 1997). Such "follow the actors" approach, characteristic of STS, avoids "dichotomiz[ing] resisters and dominators", (Baaz et al.

labels problematic institutional behavior as resistance, which is, perhaps unwillingly, a political declaration whose political effects should be considered. 
2018, p 25) and highlights the relational (Wilhoit \& Kisselburgh 2017) and interactional dimensions of resistance (Hollander \& Einwohner 2004). The second nuance incorporated to my working definition of resistance is that I will not assume that the social change that resistance strives for is necessarily progressive. Instead, I argue that resistance can be oriented towards archiving any kind of social change.

Both nuances have the possibility of opening the field of Resistance Studies to the study of a plethora of resistance practices. However, in arguing for a widened scope I do not mean to suggest that there is a shortage of contentious practices to approach, but rather that the sharp tools that scholars of resistance have developed to analyze the production and maintenance of power asymmetries could productively be redirected to hitherto unaccounted phenomena to produce useful insights. In this paper, for example, I will look at how citizens experience the problematic behavior of the Mexican state, by mobilizing two concepts from the Resistance Studies literature: Everyday Forms of Resistance and Shatter Zones. My goal is to suggest that, by framing institutional practices as resistance and thus acknowledging their political dimension, we can move beyond considering institutional failure as an unintended and non-political phenomenon, highlighting instead how certain actors benefit from institutional opacity to produce and enforce power inequalities.

Everyday Forms of Resistance are commonly defined as "invariably quiet, disguised, anonymous, often undeclared forms of resisting claims imposed by claimants who have superior access to force [...]" (Scott 1989, p.37), whereas Shatter Zones refers to rough geographical spaces that exert friction to the State's attempts to exercise power, allowing for the subsistence of communities which refuse to be controlled (Scott, 2014). Adapting these two concepts to the context of transparency research, I will therefore speak of Everyday Forms of Institutional resistance; subtle institutional practices that undermine citizens' agency, and Institutional Shatter Zones; rugged institutional (digital or physical) spaces created by state actors, where information is made public without necessarily being accessible, thus also reducing citizen agency. As I will show in the following sections, these institutional strategies have the effect to diminish citizens' ability to gather information and data that allows them to act on (Milan 2019, Kubitschko 2018) data-based policies, governmental programs and in general, governmental action.

\section{Resistance to transparency in Mexico}

Although, by law, all the information produced or held by the state is public by default -with a few clear exceptions-, the RTI legal framework in Mexico has effectively created two types of PSI. On the one hand, there is information that every institution at the federal, local and municipal level is obliged to make proactively available to citizens. The General Transparency and Public Information Law (GTPIL) includes various lists of transparency obligations: a general one, which applies to every institution of the state, and other lists of specific transparency obligations that are connected to different types of institutions. Articles 70 to 79 of the GTPIL outline close to 200 general and specific transparency obligations, as well as the criteria through which the "public utility" of other governmental information should be recognized to guarantee its publicity. On the other hand, there is PSI that, although not considered in any of the lists of transparency obligations, is also public because it does not fall under any of the exceptions stated in the law.

Institutions fulfill their transparency obligations regarding the first type of information by making data available primarily through the National Transparency Platform (NTP) and their individual websites. The second type of PSI is made public by setting in motion the FOI process, which can be done by any person either through the NTP, a phone call or a visit to the transparency office of each institution. As outlined in the law, the Mexican FOI process is relatively simple: When an 
information officer receives an information request, their first task is to determine whether their institution is competent to reply. If that is not the case, they are obliged to direct the requester to the institution who may hold the information requested. Conversely, if their institution should indeed pm of the information, they have 20 days to deliver it, unless it is deemed inexistent, classified or confidential. The decision to not deliver the information can only be taken by a transparency committee within each institution, and thorough legal substantiation is required. The document containing the legal reasoning that backs up the decision to not deliver the information is then provided as the answer to the information request.

Nevertheless, as it is, to a certain extent, a normal occurrence with any public policy, the progressive Mexican FOI legal framework is not always implemented as flawlessly as it is outlined in the laws. Regarding information requests in particular, researchers have conducted over the years various evaluations to determine the responsiveness of Mexican institutions (Cejudo and Zavala 2011; Fox et al. 2011; Berliner and Elrich 2015). Some of them were conducted very soon after the first transparency law was enacted in 2002 (Gill and Hughes 2005) and others as recently as 2019 (Pocasangre and Lagunes 2019; Berliner et al. 2019). Summarizing this body of research in very broad strokes, it is possible to say that Mexican institutions have a rate of responsiveness that fluctuates around $80 \%$, although the percentage for sensitive topics such as procurement or national security drops dramatically -down to 30\% in some cases (Lagunes and Pocasangre 2019). However, this relatively high percentage of responsiveness starkly contrasts with the way in which experienced FOI users feel about the process of requesting information. This is not entirely surprising given that research has been mostly conducted on the basis of analyzing small representative samples of information requests or performing "simulated user" evaluations (Cejudo and Zavala 2011). In contrast, the experience of everyday users has received little attention. One of my most experienced informants, the director of a CSO whose work is entirely based around information requests, summarized her own experience in the following way:

Whoever imagines that with a single information request you will get the information from the state, as it is written in the law, is lying. Whoever thinks that is possible, is outside of reality. Access to information is still a process that is more about being persistent and chasing institutions, than the simple and clear process of accessing information that is outlined in the law (Interview G1818).

In the descriptions of heavy PSI users, it is possible to locate practices of resistance to transparency that affect the flow of information resulting from both the proactive transparency obligations of Mexican institutions and the information request process. However, before delving directly into these instances of resistance, it is perhaps necessary to clarify what is it that is being resisted, by discussing what is the use that information activists make of the RTI.

\section{Information requests as a tool to foster citizen engagement}

Perhaps the defining feature of an information activists is that their ultimate goal is seldomly the requested information itself. What they care about is the use they will make of it: as evidence for strategic litigation, as a tool to demand that citizens' voices are heard within decision making processes, as the basic input for campaigning against corruption, to evaluate public policies or as the basis for proposals of regulatory or public policy improvement. Activists think of the RTI as a vehicle for securing the enjoyment of other rights, as it is suggested in the following quote:

We think that using FOI generates information for advocacy. We think of transparency and access to information as "bridge" rights. That is, we think and structure our requests to obtain information that allows us to understand and tackle issues specific to our agenda. Thus, when we structure the requests with that goal, you're thinking not only in the information, but what you will do with it (Interview G2318) 
Activists understand the RTI is a "bridge" right because, in their experience, having the information to prove to the government that there is budget allocated for the construction and operation of public infrastructure can be the difference between enjoying a public service or not. Furthermore, whereas advocating for rights through the use of citizen generated data may trigger challenges coming from the state regarding the quality and objectivity of the data, PSI is unquestionable, since it is the "voice of the institutions" themselves (Interview G2218). But besides its use as a direct accountability tool, there is another way of using FOI that also increases citizens' ability to supervise the functioning of institutions: FOl's ability to reveal the inner workings of the state to miniature detail. Public officials in Mexico tend to be verbose when producing any official document. Thus, in the responses to information requests it is possible to find thorough descriptions of the networks of bureaucrats, technological systems and regulations implied by any single instance of governmental action, independently of whether the request is actually fulfilled or the information is denied. Therefore, what activists obtain from setting in motion the FOI process is always more than the specific budget, database, contract, etc., they asked for, as it is evident in the following quote:

The answers to our information requests reveal that public policies, public goods and services provided by the government are sets of chains of command that should lead to the good or service that they are supposed to provide. But our analysis of the documents reveals that, as it travels through those chains of command, public policy deviates, and what happens in the end is very different to what was planned or written in the law. If you only look at the performance data that is made public as Open Data, and how it shows the fulfilment of policy goals, it seems as if governmental action was a linear process that occurs once and that's it; that the chains of command are clear: " $A$ " leads to " $B$ ", and " $C$ " to " $D$ ". But that is not how it goes. In reality, " $A$ " leads to "pineapple" because a lot of actors intervene in the process: different public servants at different levels of government and from different institutions; budgetary [institutions], administrative [institutions], normative [institutions] and service providers (Interview G1818).

In the hands of activists, PSI becomes a blueprint containing the roads taken by governmental action in practice rather than the 'ideal' paths prescribed in laws. Thus, these maps provide productive guidance when citizens want to make sure that institutions behave in accordance to what is stated in the law. For example, one of the CSO I contacted spent a full year making information requests to find the operating budget of a policy to fight teenage pregnancy. Due to the resistance to transparency they faced from institutions, the simple question "What is the budget of policy ' $x$ '"' required more than 200 information requests to be answered. In the end, all the answers to these requests allowed the activists to trace the performance of the policy throughout the three levels of government, from its inception and regulation at the highest, to its everyday local performance at the lowest. Thus, their analysis of PSI gave them the possibility to oversee the performance of the policy by making visible every actor, regulation and technology constituting it. Another CSO contacted for this research conducted an evaluation of the state of the water treatment infrastructure in a rururban area close to Mexico City. The process of gathering the necessary PSI to inform the project took more than three years and 300 requests. With this information, the CSO was able to build a very detailed radiography of how water treatment policies operate in the region, allowing them to identify why the water treatment plants do not work -even at a technical level via the analysis of construction plans and logs-, as well as making visible what moments of the procurement process are more susceptible to corruption practices. In both cases, the RTI was not the endpoint of the activists' strategies, but a tool to achieve other rights, namely sexual and reproductive rights in the first place, and the rights to water and sanitation in the second. Both organizations are now developing citizen oversight projects to exert ex ante control over governmental action rather than ex post. 
It is precisely because the RTI has the potential to increase citizens' abilities to hold institutions accountable or participate in public decision- making processes that friction during the FOI process is characterized as resistance. The crucial role that information requests have in activists' projects is evident in the following quote:

When they [public officials] deny our requests, what happens is that we are prevented from continuing with our political activities: we don't have tools or elements to sit with decision-makers and tell them what part of the policy they are planning or implementing is deficient, because we are lacking the data that institutions refused to disclose [...] When you don't have that official information, you only have your own suppositions, which can be easily dismissed by authorities (Interview G2318).

Information activists' use of the RTI proves that PSI in particular can foster complex political engagements. My informants have developed projects fueled by information requests that go beyond accountability and try to secure citizens' involvement in governmental action in different areas: the construction of massive infrastructures -such as the heavily criticized new airport of Mexico City-, the provision of justice, fracking and mining concessions, and the everyday exercise of public budget, among others. In all these cases activists referred to have faced different practices of institutional resistance during the process of requesting information. Whether this resistance is intentional or the consequence of accidents, mistakes or incompetence is very difficult to determine. However, concern over the intentions of institutions deviates attention from something which is also extremely relevant: That these institutional practices reduce citizens' agency regardless of whether that is the goal of public officials or not. According to information activists, a denied or incomplete answer may be the difference between a successful or an unsuccessful project of advocacy or political intervention. In this sense, the state that information activists experience through their interactions with institutions is surprisingly schizophrenic. On the one hand it provides citizens with the tools to obtain information and the participation mechanisms to join decision-making processes. On the other hand, it is also a state that in many ways resists engagement by undermining citizens' agency.

\section{Practices of institutional resistance}

The instances of resistance to transparency described by my informants do not consist of organized or evidently politicized institutional action. They are subtle strategies that can always pass for accidents, such as when an email is required to receive information requested by phone -a mechanism specifically set up for citizens without access to computers-, misunderstandings, such as when officials interpret requests in a manner that results in the provision of as little information as possible, and incompetence, such as when the information is provided in carelessly scanned PDFs which are unreadable. These and other acts are the norm rather than the exception during the FOI process, and requesters need to implement, every time, strategies to predict and counteract them. It is thus a type of resistance "that is done routinely, but which is not politically articulated or formally organized [...] a form of activity that often avoids being detected as resistance" (Vinthagen and Johansson 2013, p. 10).

The first challenge when using FOI is to draft the text of the information request itself. According to my informants this may take up to two days of work, since public officials will take advantage of any mistake, vagueness or inaccuracy in the request to dismiss it:

They [public officials] know every possible way of resisting, from A to Z. If you don't specify a year in your request, they will deny it. If you do not specify what particular document you want, they will deny it. If you do not back up your request with the relevant articles from the law, they will argue they are not 
obliged to provide the information, and deny it. Or they will give you other information. If your request is not clear enough, it will be considered vague and will not be answered. (Interview G0318)

Resistance during the initial stages of an information request can be counteracted by having thorough knowledge of the inner workings of the state, the competencies and the scope of action of institutions, their internal hierarchies and their archival practices. Experienced activists who are aware of all these factors take pride in writing information requests which are impossible to dismiss or deny due to their detailed structure, and jokingly refer to instances in which even public officials have expressed surprise at the thoroughness of the requests. This knowledge may, however, not be enough to guarantee that an information request will be successful. Public officials will often resort to technological arguments to not disclose information, as well as to dislocate their responsibility over that decision, turning it into a technical rather than a political matter. For example, they may ask requesters to physically show up to their offices to pick up the information because it cannot be reproduced digitally. If there is indeed a digital version of the information, they may argue that it cannot be sent over the internet because files are too big or their computers lack enough processing power to handle documents. In these examples institutional resistance is eminently sociotechnical -and thus, relational-in nature: to be exerted and justified, it requires the presence of technical means. In fact, technology is one of the main forms through which the contentious dimension of public officials' actions remains hidden, as it is not the behavior of officials which prevents disclosure, but the non-political inadequacies of the technology.

Institutional Resistance to transparency can take the radical form of data destruction. Eight out of my 15 informants have received at least once as an official reply to their information requests that the data could not be provided because archives had been damaged, lost or data was never archived. As I write these lines in April 2019, one of the biggest Mexican newspapers showcases on its front page an article about the large amount of data lost to fires, floods or simply gone missing, including the court files related to the high-profile murder of an activist, the trial of a union leader accused of corruption, and part of the historic archive of a university, which was sent to a paper recycling company (Zavala 2019). In late March, 2019, three floors of the central offices of the National Waters Commission caught fire during a weekend, amidst rumors of a possible official audit. Two of my informants who work in matters related to water and sanitation expressed concern via e-mail about the affectations that the fire might have had over the data held by the institution. The fire initiated in the floor that houses the archives of water concessions, currently a controversial topic in Mexican politics.

All these cases have received considerable media attention. However, they have not been politicized beyond civil society circles. In fact, the routine destruction of official data is often portrayed as a matter of the everyday incompetence of public officials or as the consequence of a lack of proper funding that allows them to maintain appropriate archives, which is also undoubtedly true. Nevertheless, research on similar obfuscation practices performed by users of digital technologies has shown how it is possible to reduce the value of data by "adding noise to an existing collection of data in order to make the collection more ambiguous, confusing, harder to use" (Brunton \& Nissenbaum 2011). In that sense, the seemingly non-political nature of routine data hampering should not obscure that, in a time in which the assemblage of publics through data processing and analysis (Ruppert 2017) is increasingly becoming one of the most effective forms of political intervention, destroying, altering or making difficult access to data is an effective strategy to guarantee that publics cannot prosper (cfr. Marres 2005).

While it is during the process of requesting information that activists are the most exposed to institutional resistance to transparency, accessing the information described in the general and 
specific transparency obligations can also be extremely problematic. Data and information related to the budget and regulations of public policies and governmental programs are commonly scattered across legal documents produced and archived by offices from different levels of government, rather than being unitary entities that can be easily accessed and understood by citizens, as the law demands. These practices result in what could be called, in analogous fashion to Scott's argument in The Art of Not Being Governed (2014), institutional shatter zones. These rugged institutional landscapes make extremely difficult for interested parties to evaluate the performance of public policies or identifying opportunities for citizen involvement. In the best scenario, activists may have to divert human and economic resources they could invest in accompanying the implementation of the policy to first clarify its components and development. At worst, they may end up being completely excluded. And while a certain degree of complexity is to be expected in public administration, what is concerning is how many times institutional shatter zones have been used to avoid accountability and allow the flow of money to private hands in corruption scandals. A particularly controversial case came to light in 2017, when a group of journalists published a piece of research called La estafa maestra (The master con), showing how a complex network of institutions and service suppliers was assembled in order to steal around 400 million U.S. dollars (Castillo et al. 2017). The research was carried out chiefly through information requests, of which journalists made 517, to trace the flow of money through the state infrastructure. Just three years before, a similar journalistic research denounced how the intricate structure of the flows of money from the federation to the municipalities was used to funnel illegal economic resources to political parties during election time (Olvera 2017).

These two examples are, however, extraordinary cases of something that is experienced by information activist on a daily basis, since the text of information requests is the most common example of institutional shatter zones. In the opinion of activists, the language used by information officers to respond to requests is perennially obscure, complex and intricate. Responses usually include copious references to federal and local laws, internal regulations, and institutional documents which are not necessarily known to activists before they receive the answer to their request. Making sense of these replies requires a level of expertise that not every citizen can acquire. In fact, the intricateness of institutional responses is one of the main reasons why activists feel that the RTI in Mexico has not been appropriated by more actors apart from certain journalists and civil society groups. My informants described the language of the responses as "totally specialized" and "not a citizen language. They [public officials] constantly use the language of authority, creating labyrinths in the information they provide" (Interview G2318). Even the structure of the responses is difficult to navigate, particularly when requests are denied, appealed by activists, and then granted by a higher authority. In those cases, the file received by the requester may reach hundreds of pages, many of which consist of literal quotes of other parts of the same document. At least two of my informants expressed having trouble believing that the complexity of official responses is not a deliberate strategy to hinder their access to public information.

As the Mexican government incorporates new technologically mediated practices of open government, digital institutional Shatter Zones are also created. The best example is the National Transparency Platform, conceived as the main tool to manage transparency at all levels of government. Ideally, the PNT would allow citizens to file, track and manage information requests, as well as enable authorities to archive in a single place and make public all the information the law states should be made proactively transparent. Nevertheless, the platform is plagued by bugs that make it difficult to operate, and institutions make opportunistic use of the affordances of the software to derail the FOI process: 
If you start filing a request, sometimes it will disappear. Even if the platform gave you an identification number. It's like it never existed. This is a way of avoiding giving you information [...] The most difficult part is when you want to appeal an official response. You have to be constantly checking the platform to make sure they haven't tried to contact you, because if they did and you don't reply, the process may be discarded. (Interview G2218).

The platform also enforces different rules for citizens and authorities: whereas deadlines are fixed and final for citizens (i.e., not responding to an institutions' plea to clarify a request will automatically legitimize an information denial), they are flexible for authorities, who may take longer to respond than what is allowed by law, without consequences.

Something similar happens with the data repositories created by institutions to fulfill their transparency obligations. These repositories have intricate structures that restrict their usability and are often plagued with dead links given the frequency with which they are updated. Since each new administration may build its own data repositories, learning to navigate them will only be temporarily useful. To make things more complicated, these repositories are often referenced in answers to information requests, generating a sort of nesting of shatter zones. Requesters who manage to successfully take the FOI process to completion may find, somewhere within the legalistic language of the response, a statement informing that the data is already public and can be accessed by following a link to an official data repository contained in an attached passwordprotected Microsoft Excel File... only to find that the link is broken. This cartoonish scenario is not an exaggeration.

Institutional shatter zones hinder citizens' access to information in the same seemingly nonpolitical way that characterizes the everyday forms of resistance approached before. Here again, the difficulty of distinguishing malice from incompetence makes talking about resistance problematic. For example, shattered institutional landscapes often result from legitimate attempts to improve the Mexican legal framework and its technological tools. However, taking the perspective of activists highlights how the mere existence of these obstacles, regardless of whether they are intentionally set to hinder citizens' endeavors or not, decreases the legibility of the state, in whose rugged landscape thrive corruption, nepotism, and inefficient public management. Therefore, just like the rugged spaces in Zomia allow peasants to avoid control (Scott 2014), institutional shatter zones may allow governmental action to happen far from citizen's watchful eyes.

Despite how disempowering the aforementioned strategies of resistance can be, activists often manage to gain agency through various countermeasures. In fact, activists' research methodologies have been adapted to accommodate the resistance strategies of the state and mitigate their impact. Institutional resistance has triggered a capacity-building process through which citizens get increasingly better at making sense of state action, forecasting the possible outcomes of institutional procedures -and FOI responses- and ultimately, strengthening their claims to join decision-making processes. Seasoned requesters organize their activities with the goal of reducing the effect that the expected institutional resistance will have over their work. Within this process of thinking the state from outside the state, activists' experience of institutional resistance becomes a heuristic device to make sense of governmental action and more importantly, to understand power flows to improve their relative power position vis a vis institutions. Institutional resistance has therefore a surprisingly productive role: Used as a heuristic device, it turns information activists into pragmatic actors who, through their enquiries about how power relations are determined by regulations and officials' behaviour, attempt to change them. Here, resistance is more than a practice and becomes a certain sensibility, a way of 
looking at the organization of collective life with a focus on how allocations of power are enacted, contested and justified (cfr. Foucault 1982).

\section{Conclusions}

In this paper I have suggested that information activists' use of transparency mechanisms sometimes triggers adverse institutional reactions. I have argued that, since these institutional responses diminish activists' agency, they can be understood as practices of resistance despite being enacted by the, prima facie, structurally more powerful actor. In order to clarify the notion of resistance to transparency and tackle the difficulty of distinguishing between political resistance and resistance as an unintended product of incompetence, I approached the problematic practices of the Mexican state through two concepts commonly used in the study of resistance: Everyday forms of resistance and shatter zones. Both concepts allowed me to suggest that institutions can practice questionable, although not illegal, resistance to transparency through seemingly non-political strategies that nevertheless have very political effects according to the activists who experience them. By focusing on how institutional behavior affects the agency of heavy FOI users and implementing a Resistance Studies-inspired approach, I foregrounded the politics of institutional resistance to transparency, something that previous literature had trouble doing.

Throughout my analysis, information and communication technologies have appeared as objects of contention structuring the actions of citizens and institutions. It is data and information, the practices of producing, distributing and analyzing them, and the technologies that make these practices possible, what are used to resist or strengthen citizen agency. Surprisingly, both citizens and institutions are enabled by almost the same tools and resources. Although the latter have a much more privileged access to PSI, the means to process it and, arguably, a higher dominion of the legal frameworks that determines how it can be used, information activists are not far behind. Their data practices and demands for information resources suggest that their understanding of transparency is connected to the possibility of tracing, without deviations or disconnections, the flow of power that results in a particular governmental act. In that sense, the transparency that information activists pursue goes beyond the bare making of PSI available, and calls for deeper institutional care and concern for the context in which data is produced, communicated and used, since it affects citizens' possibilities for political engagement.

The discrepancy between RTI's progressive regulation in Mexico and its abysmal performance signals a clash between two different ways of understanding the role of data and PSI in modern democracies. This is of course not exclusive to Mexico. Whereas the state gathers, processes and produces data under the rationale of ruling, much in the fashion that James $\mathrm{C}$. Scott described in Seeing Like a State (2018), information activists strive for a form of governance in which processing data not only legitimizes their inclusion as experts in decision making processes, but also allows them to scrutinize, politicize and, ultimately, control state action. This paper has been an attempt to shed light over the conflict between these two rationales by focusing on the experiences of skilled information activists in one country. However, further attention is needed over how citizens with a less privileged access to technology make use of PSI, as well as over how they develop strategies to deal with institutional resistance.

\section{Acknowledgments}

This project has received funding from the European Research Council (ERC) under the European Union's Horizon 2020 research and innovation program (grant agreement No 639379-DATACTIVE, awarded to Stefania Milan as Principal Investigator. See https://data-activism.net). The author 
wishes to thank Lonneke van der Velden, Stefania Milan, Niels ten Oever and two anonymous reviewers for their comments and suggestions to improve this paper.

\section{References}

Access Info. (n.d.). Global Right to Information Rating | What do you want to Know? Retrieved August 2, 2017, from http://www.rti-rating.org/

Ackerman, J., M., \& Sandoval-Ballesteros, I. (2006). The Global Explosion of Freedom of Information Laws. Admin. L. Rev, 85.

Almanzar, T., Aspinwall, M., \& Crow, D. (2018). Freedom of information in times of crisis: The case of Mexico's war on drugs. Governance, 31(2), 321-339. https://doi.org/10.1111/gove.12289

Baaz, M., Lilja, M., \& Vinthagen, S. (2018). Researching resistance and social change: A critical approach to theory and practice. London; New York: Rowman \& Littlefield International.

Bauhr, M., \& Nasiritousi, N. (2012). Resisting Transparency: Corruption, Legitimacy, and the Quality of Global Environmental Policies. Global Environmental Politics, 12(4), 9-29. https://doi.org/10.1162/GLEP a 00137

Bennett, C. J. (1997). Understanding Ripple Effects: The Cross-National Adoption of Policy Instruments for Bureaucratic Accountability. Governance, 10(3), 213-233. https://doi.org/10.1111/0952-1895.401997040

Berliner, D., \& Erlich, A. (2015a). Competing for Transparency: Political Competition and Institutional Reform in Mexican States. American Political Science Review, 109(01), 110-128. https://doi.org/10.1017/S0003055414000616

Berliner, D., \& Erlich, A. (2015b). Competing for Transparency: Political Competition and Institutional Reform in Mexican States. American Political Science Review, 109(01), 110-128. https://doi.org/10.1017/S0003055414000616

Bertot, J. C., Jaeger, P. T., \& Grimes, J. M. (2010). Using ICTs to create a culture of transparency: Egovernment and social media as openness and anti-corruption tools for societies. Government Information Quarterly, 27(3), 264-271. https://doi.org/10.1016/j.giq.2010.03.001

Birchall, C. (2011). Transparency, Interrupted: Secrets of the Left. Theory, Culture \& Society, 28(7-8), 60-84. https://doi.org/10.1177/0263276411423040

Braman, S. (2009). Change of state: Information, policy, and power. MIT Press.

Brobbey, V., Excell, C., Kakuru, K., \& Tilley, A. (2013). Active and Passive Resistance to Openness: The Transparency Model for Freedom of Information Acts in Africa - Three Case Studies. Retrieved from The Access Initiative website: https://accessinitiative.org/resources/active-andpassive-resistance-openness-transparency-model-freedom-information-acts-africa-

Brunton, F., \& Nissenbaum, H. (2011). Vernacular resistance to data collection and analysis: A political theory of obfuscation. First Monday, 16(5). https://doi.org/10.5210/fm.v16i5.3493

Calland, R., \& Bentley, K. (2013). The Impact and Effectiveness of Transparency and Accountability Initiatives: Freedom of Information. Development Policy Review, 31, s69-s87. https://doi.org/10.1111/dpr.12020

Castillo, M., Roldan, N., \& Ureste, M. (2017). La Estafa Maestra. Retrieved from Animal Político website: https://www.animalpolitico.com/estafa-maestra/

Cejudo, G. M., \& Zavala, D. (2011). Procesos y Prácticas del acceso a la información: Un ejercicio de ususario simulado. Retrieved from http://repositoriodigital.cide.edu/bitstream/handle/11651/823/106988.pdf?sequence=1\&isAllowed=y

Daintith, J., \& Martin, E. A. (Eds.). (2005). A dictionary of science (5th ed). Oxford ; New York: Oxford University Press.

Darch, C., \& Underwood, P. G. (2005). Freedom of information legislation, state compliance and the discourse of knowledge: The South African experience. International Information \& Library Review, 37(2), 77-86. https://doi.org/10.1080/10572317.2005.10762668 
Darch, C., \& Underwood, P. G. (2010). Freedom of information and the developing world the citizen, the state and models of openness. Oxford: Chandos.

Eom, S.-J. (2014). Improving Governmental Transparency In Korea: Toward Institutionalized and ICT-Enable Transparency. The Korean Journal of Policy Studies, 29(1), 70-100.

Fenster, M. (2015). Transparency in search of a theory. European Journal of Social Theory, 18(2), 150167. https://doi.org/10.1177/1368431014555257

Fox, J. (2007). The uncertain relationship between transparency and accountability. Development in Practice, 17(4-5), 663-671. https://doi.org/10.1080/09614520701469955

Fox, J. A. (2015). Social Accountability: What Does the Evidence Really Say? World Development, 72, 346-361. https://doi.org/10.1016/j.worlddev.2015.03.011

Fox, J., Haight, L., \& Palmer-Rubin, B. (2011). Proporcionar Transparencia: ¿Hasta Qué Punto Responde el Gobierno Mexicano a las Solicitudes de Información Pública? Gestión y Política Pública, 20(2).

Gaventa, J., \& McGee, R. (2013). The Impact of Transparency and Accountability Initiatives. Development Policy Review, 31, s3-s28. https://doi.org/10.1111/dpr.12017

Gentile, P. (2009). Resisted Access? National Security, the Access to Information Act and Queer(ing) Archives. Archivaria, 68(Fall).

Gill, J., \& Hughes, S. (2005). Bureaucratic Compliance with Mexico's New Access to Information Law. Critical Studies in Media Communication, 22(2), 121-137. https://doi.org/10.1080/07393180500072038

Gingras, A.-M. (2012). Access to information: An asset for democracy or ammunition for political conflict, or both?: The Access-to-Information Regime In Canada. Canadian Public Administration, 55(2), 221-246. https://doi.org/10.1111/j.1754-7121.2012.00215.x

Haraway, D. (1988). Situated Knowledges: The Science Question in Feminism and the Privilege of Partial Perspective. Feminist Studies, 14(3), 575-599. https://doi.org/10.2307/3178066

Hollander, J. A., \& Einwohner, R. L. (2004). Conceptualizing Resistance. Sociological Forum, 19(4), 533-554. https://doi.org/10.1007/s11206-004-0694-5

Hood, C. (2010). Accountability and Transparency: Siamese Twins, Matching Parts, Awkward Couple? West European Politics, 33(5), 989-1009. https://doi.org/10.1080/01402382.2010.486122

hooks, bell. (1989). Talking back: Thinking feminist, thinking black (1st ed). Toronto, Ont., Canada: Between the Lines.

Johansson, A., \& Vinthagen, S. (2016). Dimensions of Everyday Resistance: An Analytical Framework. Critical Sociology, 42(3), 417-435. https://doi.org/10.1177/0896920514524604

Kazansky, R., \& Milan, S. (Forthcoming). The politics and ethics of studying (data) activism. DATACTIVE Ethics Working Paper Series.

Kubitschko, S. (2018). Acting on media technologies and infrastructures: Expanding the media as practice approach. Media, Culture \& Society, 40(4), 629-635. https://doi.org/10.1177/0163443717706068

Lagunes, P., \& Pocasangre, O. (2019). Dynamic transparency: An audit of Mexico's Freedom of Information Act. Public Administration, 97(1), 162-176. https://doi.org/10.1111/padm.12553

Law, J. (2002). Aircraft stories: Decentering the object in technoscience. Retrieved from http://public.eblib.com/choice/publicfullrecord.aspx?p=1167762

Lilja, M., Baaz, M., Schulz, M., \& Vinthagen, S. (2017). How resistance encourages resistance: Theorizing the nexus between power, 'Organised Resistance' and 'Everyday Resistance.' Journal of Political Power, 10(1), 40-54. https://doi.org/10.1080/2158379X.2017.1286084

Marres, N. (2005). No Issue, no public: Democratic deficits after the displacement of politics. Retrieved from https://dare.uva.nl/search?identifier=b560e412-6abd-44bd-be7a-1122b4bda308

Meijer, A. (2013). Understanding the Complex Dynamics of Transparency. Public Administration Review, 73(3), 429-439. https://doi.org/10.1111/puar.12032 
Milan, S. (2019). Acting on data(fication). In H. Stephansen \& E. Treré (Eds.), Citizen Media and Practice: Currents, Connections, Challenges (pp. 212-226). London: Routledge.

Miller, L. L. (1997). Not Just Weapons of the Weak: Gender Harassment as a Form of Protest for Army Men. Social Psychology Quarterly, 60(1), 32-51. https://doi.org/10.2307/2787010

Mol, A. (1999). Ontological Politics. A Word and Some Questions. The Sociological Review, 47(1_suppl), 74-89. https://doi.org/10.1111/j.1467-954X.1999.tb03483.x

Olvera, D. (2017, June 13). El "país de los moches" es una fiesta: Sí, escándalos, mentiras y videos, pero nadie pisa la cárcel. Sinembargo.Mx. Retrieved from https://www.sinembargo.mx/1306-2017/3239628

Pasquier, M., \& Villeneuve, J.-P. (2007). Organizational barriers to transparency: A typology and analysis of organizational behaviour tending to prevent or restrict access to information. International Review of Administrative Sciences, 73(1), 147-162. https://doi.org/10.1177/0020852307075701

Peisakhin, L., \& Pinto, P. (2010). Is transparency an effective anti-corruption strategy? Evidence from a field experiment in India: Transparency and corruption. Regulation \& Governance, 4(3), 261-280. https://doi.org/10.1111/j.1748-5991.2010.01081.x

Relly, J. E. (2012). Freedom of Information Laws and Global Diffusion: Testing Rogers's Model. Journalism \& Mass Communication Quarterly, 89(3), 431-457. https://doi.org/10.1177/1077699012447921

Roberts, A. (2006). Blacked out: Government secrecy in the information age. Cambridge; New York: Cambridge University Press.

Rumbul, R. (2016). Developing transparency through digital means? Examining institutional responses to civic technology in Latin America. JeDEM - EJournal of EDemocracy and Open Government, 8(3), 12-31. https://doi.org/10.29379/jedem.v8i3.439

Ruppert, E., Isin, E., \& Bigo, D. (2017). Data politics. Big Data \& Society, 4(2), 205395171771774. https://doi.org/10.1177/2053951717717749

Savage, A., \& Hyde, R. (2014). Using freedom of information requests to facilitate research. International Journal of Social Research Methodology, 17(3), 303-317. https://doi.org/10.1080/13645579.2012.742280

Scott, J. C. (1989). Everyday Forms of Resistance. In F. D. Colburn (Ed.), Everyday Forms of Peasant Resistance. New York, NY, USA: Taylor \& Francis.

Scott, J. C. (2014). The art of not being governed: An anarchist history of upland Southeast Asia. Yale University Press.

Scott, J. C., \& Kramer, M. (2018). Seeing like a state: How certain schemes to improve the human condition have failed.

Shaw, S. M. (2001). Conceptualizing Resistance: Women's Leisure as Political Practice. Journal of Leisure Research, 33(2), 186-201. https://doi.org/10.1080/00222216.2001.11949937

Smith, D. E. (2005). Institutional ethnography: A sociology for people. Walnut Creek, CA: AltaMira Press.

Terrill, G. (2000). Individualism and freedom of information legislation. Freedom of Information Review, 30.

Transparency International. (2017). Corruption Perceptions Index 2016. Retrieved August 2, 2017, from Corruption Perceptions Index 2016 website: https://www.transparency.org/news/feature/corruption perceptions index 2016

Vinthagen, S., \& Johansson, A. (2013). 'Everyday resistance': Exploration of a concept and its theories. Resistance Studies Magazine, 1(1), 1-46.

Wilhoit, E. D., \& Kisselburgh, L. G. (2017). The relational ontology of resistance: Hybridity, ventriloquism, and materiality in the production of bike commuting as resistance. Organization, 135050841772371. https://doi.org/10.1177/1350508417723719 
World Justice Project. (n.d.). WJP Open Government Index 2015. Retrieved August 2, 2017, from World Justice Project website: https://worldjusticeproject.org/our-work/wjp-rule-lawindex/wjp-open-government-index-2015

Worthy, B. (2010). More Open but Not More Trusted? The Effect of the Freedom of Information Act 2000 on the United Kingdom Central Government: FREEDOM OF INFORMATION ACT 2000 AND THE UNITED KINGDOM. Governance, 23(4), 561-582. https://doi.org/10.1111/j.14680491.2010.01498.X

Zavala, S. (2019, April 13). "Pierden" expediente de Elba Esther y pruebas del asesinato de Samir Flores. El Universal. Retrieved from https://www.eluniversal.com.mx/nacion/seguridad/pierden-expediente-de-elba-esther-ypruebas-del-asesinato-de-samir-flores

Zuiderwijk, A., \& Janssen, M. (2014). Open data policies, their implementation and impact: A framework for comparison. Government Information Quarterly, 31(1), 17-29. https://doi.org/10.1016/j.giq.2013.04.003 